\title{
KONSEP KETUBUHAN DALAM ASMARA BERDARAH KEN AROK KEN DEDES: KAJIAN FEMINISME SIMONE DE BEAUVOIR
}

\author{
Jalu Norva Illa Putra \\ Universitas Udayana \\ Posel: jalunorva@unud.ac.id \\ Artikel dikirim: 16 September 2021; Diterima: 20 Oktober 2021

\section{THE CONCEPT OF THE BODY IN ASMARA BERDARAH KEN AROK KEN DEDES: SIMONE DE BEAUVOIR'S FEMINISM}

\begin{abstract}
The discussion about feminism never ceases to be debated in all aspects. Women and men are always contested about who is "the most". This paper looks at this aspect more fundamentally through a novel entitled Bloody Asmara Ken Arok Ken Dedes. The concept of the body in this work is useful for establishing a legitimacy for power and recognition. Until in the end this body discourse was overturned by the resistance about body ownership. Ken dedes won to be a subject that is able to stand alone and even become a domineering person.
\end{abstract}

Keywords: feminism, the body, patriarchy, Simone de Beauvoir

\section{PENDAHULUAN}

Perempuan hadir dengan sebuah konsep terkait hubungannya dengan laki-laki. Banyak perbincangan yang membicarakan tentang dominasi laki-laki atas perempuan. Tulisan ini juga akan melihat bentuk dominasi tersebut dalam sebuah konsep tubuh. Objel penelitian yang diambil adalah sebuah novel yang berjudul Asmara Berdarah Ken Arok Ken Dedes karya dari Tjahyaningtyas. Secara singkat novel ini bercerita tentang kisah berdarah dari Ken Arok dan Ken Dedes. Dengan sebuah inovasi yang agak berbeda novel ini di buat. Sisi Ken Dedes lebih ditonjolkan dalam penceritaannya. Ken Dedes menjadi latar dari Ambisi Ken Arok untuk menjadi Raja. Objek ini akan dilihat dalam perspektif konsep tubuh dari simone de Beauvoir.

Beberapa hal yang akan dibahas adalah tentang bagaimana konsep tubuh dalam novel tersebut, penggambaran sang Diri dan Sang Liyan, serta bentuk resistensi kepemilikan tubuh perempuan. Tulisan ini menggunakan metode tstudi pustaka dan pembacaan cermat.

Teori yang akan dipergunakan dalam melakukan analisis adalah teori milik Simone de Beauvoir. Cixous (dalam Beauvoir terjemahan, 2003:105) menyatakan "Tubuh laki-laki membutuhkan integritas karena tubuhnya merupakan bagian-bagian yang membentuk suatu yang utuh, sedangkan tubuh perempuan tidak terdiri dari objek parsial." 
Perempuan dikatakan berbeda dari laki-laki, ia bisa membentuk kesatuan yang utuh. Perempuan dapat membentuk suatu hal yang utuh tanpa menggangu kesatuan tubuhnya, ia bisa berbagi dengan hal lain di luar tubuhnya. Seperti yang dikatakan Cixous (Beauvoir, 2003:106) "Tubuh perempuan memiliki kapasitas untuk membagi dengan tidak memikirkan diri sendiri, tubuh yang tanpa ujung, tanpa anggota, tanpa bagian yang paling penting. Tubuh perempuan adalah kesatuan yang utuh yang senantiasa selalu bergerak dan berubah."

Hal itu sejalan dengan pendapat Beauvoir (dalam Prabasmoro 2006:59) yang mendefinisikan tubuh sebagai sebuah situasi, tubuh dikatakan sebagai cengkraman manusia terhadap dunia dan sketsa dari impian-impian manusia. Tubuh selalu berhubungan dengan subjektivitas individual perempuan dan lakilaki. Di lain sisi Spinoza menyampaikan pendapatnya sendiri bahwa tubuh manusia akan bermanfaat apabila mampu merepresentasikan Tuhan pada setiap kegiatannya (Woolhouse, 1993: 31). Hal ini memberikan sebuah legitimasi baru bahwa perempuan memiliki kesempatan yang sama atas tubuhnya seperti halnya laki-laki. Salah satu filsuf modern yang ikut menyempurnakan makna ketubuhan adalah Gottfried Wilhem Leibniz. Leibniz menganggap tubuh sebagai automata atau mesin yang paling sempurna bagi manusia (Bennett, 2017: 1).

Perempuan dapat menjadi perempuan dengan cara yang diinginkannya, sesuai dengan caranya memaknai dan menubuhi tubuhnya." Perempuan dimaknai sebagai jenis kelamin (seks) yang dalam pandangan ahli feminisme seringkali dibedakan dengan gender. Seks dikatakan sebagai sebuah suatu fakta biologis atau ilmiah yang membedakan antara jenis kelamin laki-laki dan perempuan, sedangkan gender adalah suatu hal yang bersifat historis, kultural, atau sosial.

Tubuh perempuan bukan hanya tubuh itu sendiri melainkan bagian yang terpenting dalam diri perempuan. Tubuh perempuan di sini tidak dapat dikatakan sebagai alat dari tubuh yang lain (laki-laki). Tubuh perempuan tidak seperti tubuh laki-laki yang membutuhkan integritas karena tubuh perempuan merupakan objek parsial. Perempuan memiliki kapasitas untuk membagi dengan tidak memikirkan diri sendiri, tubuh yang tanpa ujung, tanpa tubuh dan tanpa ujung, tanpa anggota, tanpa "bagian" yang paling penting. Jika tubuh perempuan adalah utuh maka keutuhannya terdiri dari bagian-bagian yang utuh, bukan sekadar objek parsial, melainkan suatu rangkaian yang terus menerus bergerak dan berubah.

Apabila berbicara tentang tubuh sebagai sebuah anggota badan tentunya perempuan dan laki-laki memiliki perbedaan, inilah yang dinamakan sebagai kodrat. Di sisi lain Thomas Hobbes yang menyatakan bahwa perempuan lebih unggul di dalam merawat anakanaknya sedangkan laki-laki lebih berkuasa di dalam 
kehidupan berumah tangga (Agonito, 1977: 95). Pendapat ini merupakan sebuah keseimbangan yang lain. Kesetaraan bukanlah sesuatu yang persis, setara adalah tentang sebuah keseimbangan.

Dalam Second Sex, Beauvoir (2003:208) menyatakan bahwa kesubjekkan laki-laki membuat ia merasa lebih berkuasa dan memiliki kemampuan yang lebih dibandingkan perempuan. Hal inilah yang menimbulkan adanya sebutan Sang Diri untuk laki-laki dan sebutan Sang Liyan (other) untuk perempuan atau dalam penyebutan yang lain dapat dikatakan bahwa, laki-laki adalah subjek, sedangkan perempuan adalah objek. Jika liyan selama ini dikatakan sebagai ancaman bagi sang diri, perempuan adalah ancaman laki-laki karena itu jika laki-laki ingin bebas, lakilaki harus mensubordinasi perempuan terhadap dirinya. Konsep mengenai sang diri dan liyan merupakan sebuah konsep yang unik. Relasi antara laki-laki dan perempuan dikatakan sebagai etre pour les autres atau hubungan relasi antarmanusia. Namun sayangnya, dalam hubungan antarmanusia tersebut perempuan dianggap sebagai objek (others) oleh laki-laki. Hal ini yang menyebabkan perempuan menjadi tersubordinasi.

Konsep mengenai sang diri dan sang liyan ini terlihat jelas dalam budaya patriaki. Dalam budaya patriaki, tubuh perempuan dikonsumsi sebagai objek pandangan, objek sentuhan, objek seksual, dan objek ideologi. Seperti yang dikemukakan Beauvoir sebelumnya bahwa tubuh bukanlah suatu benda, tubuh adalah situasi, tubuh adalah cengkraman kita terhadap dunia dan sketsa dari proyek-proyek kita. Namun, dalam pemaknaan perempuan, perempuan tidak dapat mengambil fungsi tersebut.

Beauvoir (dalam Prabasmoro, 2006:59) menyatakan "Tubuh perempuan lebih dari sekadar faksitisitas, lebih dari sekadar fakta biologis. Tubuh adalah bagian dari kemanusiaannya. Hal inilah yang menjadi kontradiksi dalam diri perempuan. Sebagai manusia ia adalah subjek, sedangkan sebagai seorang perempuan ia adalah liyan yang absolut, perempuan adalah objek. Persinggungan sebagai subjek dan objek dalam waktu yang bersamaan akan menghasilkan objektivikasi."

Sebagai sang diri, laki-laki kerap kali membuat dirinya berkuasa yang tanpa ia sadari bahwa kekuasaannya tersebut justru dibantu oleh keterlibatan perempuan itu sendiri. Seperti yang dikemukan Hegel (dalam Beauvoir terj, 2003:94) bahwa hubungan antara tuan dan budak jauh lebih baik daripada hubungan antara laki-laki dan perempuan. Kelebihan sang tuan berasal dari penegasan tentang jiwa sebagaimana terhadap kehidupan melalui fakta bahwa ia mempertaruhkan nyawanya sendiri. Tapi kenyataannya, budak yang ditaklukkan juga mengetahui risiko yang sama, sedangkan perempuan pada dasarnya adalah suatu eksistensi 
yang memberikan kehidupan tapi tidak mempertaruhkan nyawanya, antara lakilaki dan perempuan tidak terjadi pertempuran.

Konsep yang telah tertanam selama bertahun-tahun ini menjadikan perempuan bersikap pasrah dan hanya menerima keadaan dari nasib yang membelenggunya sebagai Sang Liyan. Perempuan menyerahkan dirinya secara pasif kepada kemauan laki-laki dan membiarkan terjadinya asimilasi sehingga dengan demikian laki-laki dapat memanfaatkan perempuan. Sebagai Liyan, perempuan kerapkali mengalami diskriminasi dan penindasan yang dilakukan oleh sang diri. Perempuan yang dianggap sebagai jenis kelamin kelas dua adalah sebuah kesialan. Dengan keberadaannya sebagai sosok yang lain, perempuan juga tampil sebagai makhluk yang berkelimpahan dan berkecukupan. Berlawanan dengan eksisitensi ketiadaan yang dirasakan oleh laki-laki dalam dirinya, sosok yang lain ini walaupun dipandang sebagai objek di mata laki-laki tapi kehadirannya juga dirasakan en soi (dirinya sendiri), yakni sebagai makhluk dan pencapaian sebagai suatu makhluk ini membuat perempuan mampu menonjolkan diri sebagai manusia dan makin banyak perempuan yang menonjolkan dirinya maka eksistensi mereka sebagai sosok yang lain semakin pudar sekalipun posisi sebagai sang liyan tetap eksis dalam hati tiap laki-laki. Beauvoir (2003:62) menyatakan bahwa tidak ada subjek dalam pandangannya yang menjadi subjek tanpa suatu objek dan tidak ada subjektivitas yang cukup aman karena selalu ada potensi pembalikan. Dalam hal lain ini dapat dikatakan bahwa seseorang hanya dapat menjadi sang diri kalau ia direfleksi oleh liyan dan hubungan antara subjek atau sang diri dengan objek atau sang liyan menjadi tidak terhindarkan. Hubungan subjek-objek ini menurut Beauvoir tidak selalu hubungan yang mengobjektivikasi salah satu dengan unsur yang statis. Beauvoir berpendapat bahwa suatu hubungan dapat bersifat saling membutuhkan untuk saling mengakui subjektivitas masing-masing sebagai makhluk yang bebas.

Konsep mengenai liyan dan sang diri ini pun berlaku pada jenis kelamin. Jika dikatakan bahwa semua jenis kelamin adalah manusia, lalu mengapa ada pembedaan, ada yang menjadi subjek dan ada yang menjadi objek bagi yang lain (perempuan). Konsep perempuan sebagai liyan yang dikemukakan oleh Beauvoir ini dimaksudkan sebagai wadah perjuangan bagi perempuan untuk memperoleh pengakuan yang dalam konsep Beauvoir termasuk dalam kemandirian ekonomi, intelektualitas, transformasi sosialis, dan penolakan untuk menginternalisasi suatu liyan. Tidak ada yang mutlak dan tidak ada kemandirian yang absolut serta tidak ada subjektivitas yang absolut yang bebas dari situasi pembalikkan. Antara subjek dan objek selalu tersedia kemungkinan untuk pembalikkan posisi tersebut. 
Pemikir Beauvoir hadir dengan konsep proses menjadi perempuan atau becoming a woman. Beauvoir memaparkan tentang tantangan bagi perempuan dan yang tidak pernah dialami oleh laki-laki. Selain adanya konsep other yang diasosiasikan dengan perempuan, pada karyanya The Second Sex, Beauvoir memaparkan kondisi sosial yang membentuk konsep perempuan itu sendiri. Perilaku berbeda yang dikenakan kepada perempuan merupakan hasil diskriminasi kaum patriarki yang menjadikan rahim sebagai justifikasi untuk merendahkan posisi perempuan di dalam kehidupan sosial. Hal ini lah yang menyebabkan kekangan yang dialami oleh perempuan tetap terjadi walaupun perkembangan filsafat dan ilmu pengetahuan sudah jauh melesat dari sebelumnya (Putri, 2018: 203

\section{PEMBAHASAN}

Dalam pembahasan ini akan dilihat karya Asmara Berdarah Ken Arok Ken Dedes dalam sudut pandang feminism Simone de Beauvoir. Karya ini menceritakan tentang kisah Ken Dedes dan Ken Arok yang terlibat kisah cinta dengan sedikit inovasi.

\section{Konsep tubuh dalam Asmara Berdarah Ken Arok Ken Dedes}

Ken Dedes dalam karya ini adalah seorang perempuan yang diceritakan cukup dominan dan dapat dikatakan sebagai tokoh utama. Ken dedes digambarkan sebagai seorang yang cantik luar biasa dandiperebutkan banyak orang. Hingga suatu saat kecantikannya di dengar oleh seorang Awuku yang bernama Tunggul Ametung. Ia menculik Ken Dedes untuk dijadikan permaisuri. Dalam penggalan cerita tersebut dapat dilihat bahwa kecantikan dan keelokan dari Ken Dedes menjadi sebuah tolok ukur untuk dijadikan sebagai permaisuri. Ken Dedes adalah sebuah alat yang dipergunakan Tunggul Ametung untuk mendapatkan sebuah pengakuan dari rakyatnya. Logikanya, ketika seorang pemimpin memiliki seorang istri yang cantik, maka banyak yang akan mengagguminya, hal ini akan berdampak pada legitimasi kekuasaan atas rakyatnya. Kebanggana akan menjadi sebuah pengakuan kepada sosok pemimpin pada zaman dahulu.

Ken Dedes dalam hal ini bukan lagi dianggap sebagai manusia atau perempuan, Ken Dedes ada digunakanuntuk sebuah pengakuan. Sebuah syarat untuk mendapatkan legitimasi atas sebuah kepemimpinan dengan sebuah syarat tubuh dan paras yang cantik. Tubuh yang sempurna bukan lagi menjadi suatu kelebihan, kesempurnaan itu mendorong perempuan untuk menjadi other bagi lakilaki. 
Selanjutnya dalam kondisi lain diceritakan bahwa Ken Dedes mulai terpikat dengan Ken Arok. Ken Dedes merayu Ken Arok untuk mendapatkannya. Hal ini sekilas dapat dilihat sebagai bentuk dominasi atas laki-laki. Namun faktanya Ken Dedes diibaratkan sebuah mahkota, ia adalah permaisuri ketika ia didapatkan seseorang maka harkat, martabat dan jabatannya dapat terangkat. Ken Arok melihat ini, sehingga ia berniat pula memiliki Ken Dedes, karena ketika memiliki Ken Dedes maka ia akan memperoleh status sosial yang lebih tinggi yaitu seorang Akuwu. Fakta tersebut membawa Ken arok untuk memiliki ambisius untuk menjadi Akuwu, menggantika Tunggul Ametung. Sehingga merebut Ken Dedes adalah tahap awal untuk menjadi Akuwu. Sekali lagi Ken dedes adalah sebuah alat atau sebuah jembatan untuk mewujudkan hasrat laki-laki. Perempuan hanyalah sebuah tubuh yang akan selalu dimanfaatkan untuk kebutuhan laki-laki, entah dalam status setinggi apapun.

Beberapa hal lain juga Nampak terlihat jelas ketika tubuh perempuan dipergunakan sebagai alat untuk legitimasi laki-laki. Berikut kutipan yang lainnya

"bercintalah dengan suamimu sampai dia benar-benar kecapaian. Kalau dia kecapaian, pasti dia akan tertidur lelap sekali. Saat dia terlelap itulah aku menikamnya," ungkap Arok" (Tjahyaningtyas, 2015:52)

Kutipan tersebut adalah rencana Ken Arok untuk membunuh tunggul Ametung melalui bantuan Ken Dedes. Ken Dedes diminta menjadi umpan untuk bercinta dengan suaminya agar suaminya kelelahan, hal ini gambaran jelas tentang bagaimana tubuh perempuan dipergunakan untuk keinginan lelaki. Tubuh perempuan hanyalah objek yang akan dipergunakan laki-laki untuk kebutuhannya.

Hingga pada akhirnya kepemilikan tubuh tersebut tergambar jelas ketika Ken Dedes adalah perempuan Nareswari. Perempuan Nariswari adalah perempuan yang ditakdirkan untuk menjadi ibu dari raja-raja.

“Wanita yang mengeluarkan cahaya di pangkal pahanya adalah wanita nariswari. Itu adalah wanita pilihan yang akan melahirkan raja-raja di kemudian hari. Betapapun nestapanya, laki-laki yang menikahi wanita seperti itu, ia akan menjadi raja besar"' (Tjahyaningtyas, 2015:34).

Fakta yang didapat oleh Ken arok ini menjadikan sebuah keinginan untuk menjadi penguasa dengan emmiliki Ken Dedes karena telah ada jaminan ketika memiliki Dedes maka ia akan menjadi raja Besar. Sekali lagi Ken Dedes merupakan adalah sebuah alat atau objek untuk laki-laki. 
Konsep tubuh dalam Asmara Berdarah Ken Arok Ken Dedes adalah bahwa tubuh perempuan merupakan sebuah alat untuk mendapatkan legitimasi bagi lakilaki. Laki-laki secara tidak langsung bergantung terhadap tubuh perempuan, sehingga mereka berusaha untuk melakukan subordinasi. Subordinasi dalam karya ini pada dasarnya tidak melalui paksaan fisik, namun melalui sebuah pakem budaya patriarki. Budaya Patriarki kembali lagi menjadi pintu awal atas semua dominasi laki-laki. Hal ini sangat terlihat jelas dengan konteks penceritaan dalam lingkup istana yang dipimpin oleh seorang raja dan hukumnya adalah, apa yang dititahkan raja adalah hukum.

\section{Perempuan sebagai Sang Liyan}

Beauvoir mengontestasikan antara laki-laki dan perempuan dengan istilah sang Diri dan sang Liyan. Hubungannya adalah bentuk dominasi. Asmara Berdarah Ken Arok Ken Dedes berlatar di jawa dan berada di sebuah kawasan kerajaan atau istana dan penguasanya adalah raja. Hal ini adalah poros utama dominasi tersebut.

Ken Dedes adalah sang liyan dan sang Diri adalah Tunggul Ametung.Dominasi terlihat dalam kutipan berikut:

"Setahun setelah mengabdi sebagai prajurit, Akuwu tunggul Ametung yang selama ini hanya mengencani wanita-wanita yangd itemuinya, telah menemukan sosok wanita yang dianggapnya pantas menjadi istrinya. Sayangnya ia mendapatkan wanita bernama Ken Dedes itu dengan cara menculik dari kediamannya" (Tjahyaningtyas, 2015: 19).

Tunggul Ametung melakukan dominasi melalui paksaan kepada Ken Dedes untuk menjadi istrinya. Dominas bersumber pada dua hal yang pertama karena Tunggul Ametung laki-laki dank arena ia adalah seorang Akuwu

Selanjutnya dengan kedudukan sang Diri adalah Ken Arok. Posisi ini terlihat ketika Ken Arok telah menjadi Raja, berikut kutipannya:

“Baiklah kanda sebagai seorang permaisuri aku emmang tidak boleh membantah raja yang juga suamiku sendiri" kata Dedes (Tjahyaningtyas, 2015:163)

Dominasi juga muncul melalui ken arok, walaupun Ken Arok adalah laki-laki yang mencintai Ken Dedes. Dominasi ini merupakan sebuah budaya, bahkan perempuan akan melakukan secara tidak sadar karena telah terkonsep dan menjadi konvensi sejak lama. 


\section{Upaya Perempuan Memperjuangkan Kepemilikan Tubuhnya}

Tubuh perempuan yang menjadi alat untuk dominasi atau legitimasi lakilaki telah tergambar jelas dalam ulasan siub bab sebelumnya. Pada sub bab ini akan sedikit diperlihatkan tentang bagaimana perempuan melakukan resistensi atas tubuhnya.

Ken Dedes sebagai agen feminis juga melakukan bentuk resistensi atas kendali tubuhnya. Tidak banyak Nampak, namun cukup menjadi kunci sebagai tolok ukur resistensi Ken Dedes.

Telah diketahui bahwa Ken Dedes adalah perempuan nariswari, namun kehadiran Ken Umang istri kedua dari Ken Arok merubah kedudukan yang seharusnya sudah terpatenkan. Ken Arok lebih memilih anak dari Ken Umang untuk menjadi raja penerusnya, dan Ken Dedes tidak akan menjadi perempuan nariswari lagi.

"Mendengar penuturan anaknya yang dipenuhi rasa curiga yang begitu besar, tiba-tiba muncul pemikiran jahat di benak Ken Dedes. Ia melihat kini peluang dirinya menjadi nariswari kembali terbuka lebar. Dari gelagat yang diperlihatkan Anusapati, ia melihat anak kandungnya itu akan melakukan balas dendam bila tahu kalau rajanya sendiriyang membunuh ayahnya. Dan Anusapati akan lebih mudah melampiaskan balas dendam itu mengingat ia mengetahui kebiasaan raja sehari-hari" (Tjahyaningtyas, 2015:199).

Kutipan diatas adalah bentuk resistensi dari Ken Dedes. Ken Dedes yang semula adalah nariswari yang dianggap sebagai alat untuk mendapatkan sebuah gelar raja kini berganti melawan. Kedudukan Nariswari yang dianggap sebagai legitimasi atas laki-laki kini telah berubah, karena kedudukan tersebut tidak sepenuhnya bergantung atas laki-laki, dalam hal ini ken Arok. Ken Dedes telah menjadi orang yang memegang kendali atas semuanya, membuat anaknya membunuh raja dan menjadi Nariswari tanpa seorang suami. Hal ini mengukuhkan tentang status perempuan yang mampu menjadi subjek, seperti yang dikatakan oleh Beauvoir.

\section{PENUTUP}

Konsep tentang tubuh perempuan yang seringkali menjadi wacana untuk legitimasi laki-laki masih banyak ditemukan dalam beberapa karya begitu juga dalam Asmara Berdarah Ken Arok Ken Dedes. Ken Dedes sering kali menjadi alat untuk mengukuhkan status dari Tunggul Ametung maupun Ken Arok. Konsep tubuh 
dalam karya ini adalah hal yang berguna untuk membentuk suatu legitimasi terhadap kekuasaan dan pengakuan. Hingga pada akhirnya wacana tubuh ini terjungkal dengan adanya resistensi tentang kepemilikan tubuh. Ken dedes dimenangkan menjadi subjek yang mampu berdiri sendiri bahkan menjadi orang yang mendominasi.

\section{DAFTAR PUSTAKA}

Agonito, R. 1977. History of Ideas on Woman, The Berkley Publishing. Group: New York. Beauvoir, Simone De. 2003. Second Sex vol 1. Surabaya: Pustaka Promothea

Beauvoir, Simone De. 2003. Second Sex vol 2. Surabaya: Pustaka Promothea

Bennett, J., 2017, Some Text From Early Modern Philosophy, http://www.earlymoderntexts.com/. (Diakses pada 3 September 2021)

Prabasmoro, Aquarini Priyatna. 2006. Kajian Budaya Feminis Tubuh, Sastra, dan Budaya Pop. Yogyakarta:Jalasutra.

Putri, Retno Daru Dewi G. S. 2018. "Penolakan Konsep Ketubuhan Patriarkis Di Dalam Proses Menjadi Perempuan Melalui Pemikiran Merleau-Ponty Dan Simone De Beauvoir". Jurnal Filsafat, ISSN: 0853-1870 (print); 2528-6811 (online) Vol. 28, No. 2 (2018), p. 200-219, doi: 10.22146/jf.31812. Jakarta:Universitas Indonesia.

Tjahyaningtyas. 2015. Asmara Berdarah Ken Arok Ken Dedes. Surabaya: Gramatical.

Woolhouse, R., 1993, The Concept of Substance in Seventeenth Century Metaphysics, Routledge, London

\section{PROFIL PENULIS}

Jalu Norva, S. S., M. A adalah dosen di Prodi Sastra Indonesia, Universitas Udayana. Ia banyak mefokuskan pada studi tentang Postmemory terkait peristiwa 65 maupun 98 dalam karya-karya sastra di Indonesia. Selain mengajar ia tengah menyibukkan diri untuk melihat secara lebih dekat tentang semiotika foto analog. Beberapa kali telah melakukan pemeran karya-karya fotonya baik skala kecil hingga nasional. 